\title{
Spiritual Values and Spiritual Practices: Interactive Effects on Leadership Effectiveness
}

\author{
Zakiyulfikri Ali', Muhammad Zaky²
}

\begin{abstract}
The relationship between spirituality and leadership effectiveness has been discussed over decades. These relations have been separated in two big perspective-first, an esoteric realm of intangible ideas and emotions; and second, a practical area and scientific inquiry. This research tries to integrate these two different perspectives. Specifically, this research examines the effects of spiritual values and spiritual practices on leadership effectiveness. The findings indicate that spiritual values and spiritual practices have positive effects on leadership effectiveness. This research also shows that spiritual values and spiritual practices have interactive effects on leadership effectiveness. This result implies that organizations should enhance the spiritual values and practices. Discussion, practical, and theoretical implications for further researches are offered.
\end{abstract}

Keywords: spiritual values, spiritual practices, leadership effectiveness.

\begin{abstract}
Abstrak. Hubungan antara spiritualitas dan efektivitas kepemimpinan telah dibahas selama beberapa dekade. Hubungan ini telah dipisahkan dalam dua perspektif besarpertama, alam esoterik dari gagasan dan emosi tak berwujud; dan kedua, area praktis dan penyelidikan ilmiah. Penelitian ini mencoba mengintegrasikan dua perspektif besar ini. Secara khusus, penelitian ini meneliti efek interaktif dari nilai spiritual dan praktik spiritual terhadap efektivitas kepemimpinan. Temuan menunjukkan bahwa nilai spiritual dan praktik spiritual memiliki efek positif terhadap efektivitas kepemimpinan. Selanjutnya, penelitian ini menunjukkan bahwa nilai spiritual dan praktik spiritual memiliki efek interaktif terhadap efektivitas kepemimpinan. Hasil penelitian mengindikasikan bahwa organisasi harus meningkatkan nilai spiritual dan praktek spiritual. Diskusi, implikasi praktis, dan teoritis untuk penelitian lebih lanjut ditawarkan.
\end{abstract}

Kata kunci: nilai spiritual, praktek spiritual, efektivitas kepemimpinan

\section{How to Cite:}

Ali, Zakiyulfikri., \& Zaky, M. (2018). Spiritual Values and Spiritual Practices: Interactive Effects on Leadership Effectiveness. Etikonomi: Jurnal Ekonomi. Vol. 17 (1): 123 - 134. doi: http//dx.doi.org/10.15408/etk.v17i1.6497. 


\section{Introduction}

The turning point of the historical evolution in theoretical and practical fields of management and organizational sciences has been affected by a dominant force which by proper orientation can lead to profound contribution not only in professional activities but also in all aspects of human life (Neal \& Bennett, 2000). This force is spirituality, as implementing it in organizations will be the most critical activity of the future management and any organizations cannot survive without spirituality. Although in recent decades it was predicted not to have a relationship with business activities, it had discussed in the informal literature (Mitroff $\&$ Denton, 1999). But it is supported as a serious topic for academic and scientific studies (O'connell \& Skevington, 2005). The spirituality principle in management and organization emphasized that some people described it as a fundamental transformation in management and organization field (Wagner-Marsh \& Conley, 1999). Despite gaps between the theory and practice, a growing interest in spiritual research among the academics, consultants, and philosophers of management theory is evident. There are some of professional management organizations officially supporting research and study on this subject (Javanmard, 2012).

The inclination of spirituality in the workplace has come into a considerable precedent in the present century (Beheshtifar \& Zare, 2013). It becomes in mind and has the property of inspiring (Maxwell, 2003). As the time goes on, spirituality is widely recognized. Spirituality does not only concern on ritual activities and ceremonies, but it also becomes a part of daily activities or even businesses. Over the last decade, scholars report a steady increase of interest in spirituality at work issues among management researchers and practitioners (Cavanagh, 1999). Although the literature and interest on spirituality at work is growing rapidly, there is confusion around how spirituality plays its roles.

The relation between spirituality and leadership effectiveness has been discussed over decades. For many years, these fields have been separated in at least two big perspectives: one, an esoteric realm of intangible ideas and emotions; the other, a practical area and scientific inquiry. The contradictory finding depicted the antagonist role of spirituality. Reave (2005) describes that in interviews with clergy and business leaders, clergy expressed a vague but deep hostility toward capitalism and the modern corporation, characterized by suspicion of selfishness and greed and disgust with their "unappealing but necessary function." For their part, business leaders perceived that clergy was not realistic.

Some of the literature reviews on spirituality and leadership reveals a lack of consistency and a widespread lack of consideration for the level of analysis in relation to spirituality and leadership. Some authors have a view that spirituality is an individual phenomenon (Ashforth \& Pratt, 2014), while others depict it as an organizational dynamic (Mitroff \& Denton, 1999). A very personal endeavor is sometimes directed to spirituality as in which the organization merely allows the spirituality expression while at other circumstances the organization is showing its spiritual values in a way that parallels organizational culture or mission. Some authors have asserted that "...every entity, individual or group, has a spirit" (Marques, Dhiman, \& King, 2005). The inconsistency of the relation between spirituality and leadership may occur because of some reasons: firstly, it is because of the different concept. Secondly, it is because of the different measurement. And thirdly, it is because of any 
uncontrolled variables, which may affect the relation in between those. Therefore, Analyzing the relation of spirituality and leadership is still a warm topic to be discussed.

With the dawn of a new century for global societal and organizational change, a rising and accelerating force is needed. This realization demands a more comprehensive leadership that integrates the four fundamental arenas that define the essence of human dimensions - the physical body, logical mind (rational thought), heart (emotions, feelings), and spirit (Moxley, 1999). Those dimensions influence each other in human nature. Leaders need the synergy and balance of those in order to be an effective leader. On the other hand, Leadership remains a relatively mysterious concept despite having been studied for several decades (Gupta, et al, 2005). From trait to behavioral theories, none completely explains the variety of leaders and the nature of their leadership interactions. It is understood that, at one level, leadership is a relationship between a person who influences the behavior or actions of other people. Leadership is a dynamic process that can be altered to suit a particular management philosophy (Ehigie and Akpan, 2004).

At the organizational level, leadership establishes and transmits to all employees the allembracing direction of the organization. Developing a better understanding of effective leaders is important for future leader development (Gupta et al, 2005). The European Foundation for Quality Management (EFQM) defines leadership at the strategic level as "how leaders develop and facilitate the achievement of the mission and vision, develop values required for long-term success and implement these via appropriate actions and behaviors, and are personally involved in ensuring that the organization's management system is developed and implemented" (Melchar and Bosco, 2010). From a lot of definition of leadership, we can conclude that whole definitions are directed to leadership effectiveness.

One studies to another has different concept of leadership effectiveness. But most researchers assess leadership effectiveness in terms of the consequences of the leader's influence on an individual, team, or organization. These different concepts lead the measurement of leadership effectiveness to be divided into two ways: first, by subjective evaluations from subordinates, peers, and superiors; or second, by achievement of organizational goals such as productivity and profit (Reave, 2005).

This research aims to find the interactive relationship between parameters of spiritualitydivided into spiritual values and spiritual practices - and leadership effectiveness as perceived by followers (subjective evaluation). It introduces the new point of view of spirituality and leadership effectiveness in the literature of management and organization field and presents a new approach for organizational behavior discussions.

To know deeper about the effects of spirituality in the workplace, we observe and review some literatures related to this topic. Analyzing several works that studied the same phenomena is our choice. After confirming that spirituality influences employees in the workplace, measuring the data using statistical tools will be conducted to know how these variables affected each other. The statistical result will reinforce or refute previous studies that evaluate the effects of spirituality in the workplace; and provide empirical evidence of the influence of spirituality in the workplace. 
After we reviewed the dimensions of Spirituality — spiritual values as an independent variable, spiritual practices as a moderating variable — and their connection with leadership success-leadership effectiveness as a dependent variable, we assumed that spirituality seems to offer the possibility of increasing leadership effectiveness resulting in organizational performance improvement. In addition, Spiritual development appears to allow people to be more effective if organizational goals are aligned with the areas that enhanced effectiveness, productivity should increase. Fry (2003) contends that spiritual leadership helps to create value congruence across the strategic, team and individual levels of an organization, which fosters the leadership effectiveness and generates higher levels of productivity.

\section{Method}

This study used a survey design, with a questionnaire instrument. This study was conducted at the Sunan Gunung Djati State Islamic University Bandung. The research data was taken from the lecturers' assessment of their superiors. The number of research samples was 227 respondents. Sampling method used in this research was non-probability sampling method with purposive sampling technique.

Eight question items in total of the variable of spiritual values developed by Dik et al. (2012); Francis (2013); Lee, et al (2008) were examined. The variable of spiritual practices was examined using a measure developed by Alleyne, et al (2013); Ting (2013); Hardt, et al (2012); Rafferty \& Griffin (2004); Bodling, Heneghan, Walsh, Yoon, \& Johnstone (2013) with total 12 question items. The dependent variable of leadership effectiveness was measured using a measure developed by Denison, et al (1995) covering 19 items of questions. All items were measured using five-point scale $(1=$ strongly disagree $)$ to $(5=$ strongly agree $)$.

Testing of instrument validity in this research done by using confirmatory factor analysis (CFA). According to Hair, et al (2016), an item may be considered valid if it has a factor loading value $=0.5$. While reliability testing in this study was measured by using Cronbach Alpha. The rule of thumb used for Cronbach Alpha values should be greater than 0.7, although a value of 0.6 is still acceptable (Hair et al., 2016). Hypotheses testing in this study were conducted by hierarchical regression analysis using Baron and Kenny (1986), which covered 3 stages of testing. Firstly, it examines the direct influence of the independent variables on the dependent variable (leadership effectiveness). Secondly, we examined the direct influence of the moderating variable (spiritual practices) on the dependent variable (leadership effectiveness). Thirdly, it examine the effect of interaction between spiritual values and spiritual practices on leadership effectiveness.

\section{Result and Discussion}

This research distributed questionnaires to lecturers of Sunan Gunung Djati State Islamic University of Bandung who have worked for at least 4 years as permanent lecturers. They were asked to evaluate the spiritual values, spiritual practices, and leadership effectiveness of their superiors. Table 1 presents the profiles of respondents in this study. 
Table 1. Respondent Profile

\begin{tabular}{cccc}
\hline Demography & Category & Total & Percentage \\
\hline Age & $35-40$ Year & 34 & $15 \%$ \\
& $41-45$ Year & 47 & $21 \%$ \\
$46-50$ Year & 60 & $26 \%$ \\
$51-55$ Year & 45 & $20 \%$ \\
Tenure & $>55$ & 41 & $18 \%$ \\
& $6-10$ Year & 41 & $18 \%$ \\
& $11-15$ Year & 61 & $27 \%$ \\
& $16-20$ Year & 59 & $26 \%$ \\
& $>20$ Year & 66 & $29 \%$ \\
& Male & 163 & $72 \%$ \\
& Female & 64 & $28 \%$ \\
\hline
\end{tabular}

As expected, spiritual value and spiritual practices positively related to leadership effectiveness. There was a positive relationship between spiritual values and spiritual practices. Spiritual values positively related to leadership effectiveness. Finally, there is a positive relationship between spiritual practices and leadership effectiveness. Table 2 provides descriptive statistics and correlations for all measures.

Table 2. Correlation Test

\begin{tabular}{|c|c|c|c|c|c|}
\hline Variables & Mean & Std. Dev & 1 & 2 & 3 \\
\hline Spiritual Values & 3,322 & & 1.00 & & \\
\hline Spiritual Practices & 3,014 & & $.86^{*}$ & 1.00 & \\
\hline Leadership Effectiveness & 3,145 & & $.66^{*}$ & $0.79 *$ & 1.00 \\
\hline
\end{tabular}

${ }^{* *} p<0,01 ;{ }^{*} p<0,05$

Hypotheses test in this research divided into three main steps. First, testing relationship between spiritual values and leadership effectiveness. Second, testing relationship between spiritual practices and leadership effectiveness. Third, testing the interactive effect between spiritual values and spiritual practices to leadership effectiveness. Table 3 summarizes hierarchical regressions analysis results.

At the first step, spiritual values positively related to leadership effectiveness. Spiritual values had $44.3 \%$ variance to explain leadership effectiveness. Hence, hypothesis 1 was supported. At the second step, leadership practices positively related to leadership effectiveness. Spiritual practices had 63\% variance to explain leadership effectiveness; it increased 18,8\% variance from the first steps. Therefore, hypothesis 2 was supported. At the third step, spiritual values and spiritual practices interacted to explain leadership effectiveness. The interactive effect had $67 \%$ variance to explain leadership effectiveness; it increased $4 \%$ variance from the second steps. Thus, hypothesis 3 was supported. 
Table 3. Summary of Hierarchical Regression Analysis Results

\begin{tabular}{|c|c|c|c|c|c|c|c|c|}
\hline \multirow{2}{*}{ Step } & \multirow{2}{*}{$\begin{array}{l}\text { Independent } \\
\text { Variable }\end{array}$} & \multirow{2}{*}{$\begin{array}{l}\text { Dependent } \\
\text { Variable }\end{array}$} & \multicolumn{2}{|c|}{$\begin{array}{l}\text { Unstandardized } \\
\text { Coefficients }\end{array}$} & \multirow{2}{*}{$\begin{array}{c}\mathrm{t} \\
\text { value }\end{array}$} & \multirow{2}{*}{$\begin{array}{c}p \\
\text { value }\end{array}$} & \multirow[t]{2}{*}{$\mathbf{R}^{2}$} & \multirow[t]{2}{*}{$\Delta \mathrm{R}^{2}$} \\
\hline & & & B & Std. Error & & & & \\
\hline 1 & LeadVal & LeadEff & 0,466 & 0,105 & 4,455 & $0,000^{* *}$ & 0,443 & 0,443 \\
\hline 2 & LeadPrac & LeadEff & 0,688 & 0,197 & 3,488 & $0,002^{*}$ & 0,630 & 0,188 \\
\hline 3 & $\begin{array}{l}\text { LeadVal X } \\
\text { LeadPrac }\end{array}$ & LeadEff & 0,196 & 0,117 & 1,675 & $0,005^{*}$ & 0,670 & 0,040 \\
\hline
\end{tabular}

SpiVal $=$ Spiritual Values; SpiPrac $=$ Spiritual Practices; LeadEff $=$ Leadership Effectiveness ${ }^{* *} p<0,01 ; * p<0,05$

The result shows that leadership effectiveness is affected by spiritual values. It supports whole dimensions of spiritual values-working as spiritual calling, integrity, honesty, and humility. Hypothesis 1 which states that spiritual values positively affect leadership effectiveness such that leaders who profess spiritual value will perform a greater success is supported. Hypothesis 1 emphasizes the importance of spiritual values in the workplace. These values belong to not only the leaders but also all people in workplaces. Managers should consider each point of spiritual values in order to maximize the people's performance in organizations. Spiritual values generally come from internal characters of person. Integrity and honesty, for instance, will naturally come from person's inner attitude. But the environment affects those values. Therefore, the program that train and discuss about spirituality is also important for organization in order to implement spiritual values for leaders and employees.

One of the most fundamental crises that hit the modern man is a spiritual crisis (Zohar, 2012). This crisis is characterized by dryness of search for meanings and values in life, either in relation to the self-nature or relationships meaningfulness to others, or even awareness of the 'traces' reality of truth and greatness of the Divine. This spiritual crisis contains untold impact. While, Nasr (1968) says that the emptiness of the awareness of "divine trails" causes man to become corrupt, negligent, and not grateful.

Both religion and spirituality encompass philosophical ideas about life, its meaning and purpose but spirituality has particularly a broader meaning than religion (Dyson, et al, 1997; Harrison, 1993). We can generally see that not every individual who has self-awareness, self-empowerment and self-actualization pursues a particular religious belief or faith and he is acknowledged. The process of how we interact with the world is determined by the values and practices based on spirituality. Spiritual values are proven as an important aspect to increase leadership effectiveness. However, the values should be realized the real actions. Although the spiritual practices in this research do not represent whole general practices of spirituality. In the context of leaders, spiritual practices are more concerning the leader's behavior towards subordinates or followers. Fair treatment and respecting for others' value, for example, will determine some keys of leaders' success. Finally, leaders should be aware that solid team rather than leaders themselves could only reach the vision of organization.

In spiritual practice variable, the practices are related to activities in the workplace. 
Therefore, we define spiritual practice dimensions to be respect for others' values, fair treatment, caring and concern, listening, appreciating others, reflective practice. Reflective practices are one dimension that relates to worship or beliefs of human. Twelve items are made to articulate six dimensions of spiritual practices. The result of test indicates that leadership effectiveness is affected by spiritual practices.

This study clearly proves Barret (2014) who stated that leaders who respect for others' values will creates empowerment rather than dependency, sustainability rather than shortterm success. The result also supports fair treatment in spiritual dimension that fairness creates positive working relationships and positive business outcomes. Caring, concern, and listening that are spiritual dimensions are also endorsed by the result of whole data analyses. Finally, reflective practices are also truly in line with the result of this research. Hypothesis 2 that states that Spiritual practices positively affect leadership effectiveness such that leaders who profess spiritual practices will perform a greater success is supported.

In this context of study, spiritual concerns are not the same as the concerns of any particular religions. There is even the potential clash if spirituality is viewed through particularly religious group. It can be divisive since it may deny those who do not follow the denominational tradition as well as burn the conflict of social, legal, and ethical foundations of business and public administration (Cavanagh, 1999; Nadesan, 1999).

Although researchers have already separated spirituality and religion, a lot of individuals perceive that the concepts are interchangeable (Reave, 2005). The result showed that $74 \%$ claimed themselves as both spiritual and religious (Zinnbauer et al., 1997). The distinction of spirituality and religion is needed in the study of spirituality in the workplace and in leadership in order to avoid the dangers of proselytizing and invasion of privacy. The common distinction between spirituality and religion is altruistic love-regard or devotion to the interests of others (Fry, 2003). In this respect, the fundamental-spiritual teachings of most of great existing religions are remarkably the same (Bolman and Deal, 2011). Josephson (2002) called this basic spirituality as the Golden Rule - "do unto others as you would have them do unto you" - which is common to all major religions in the Golden Rule. Fry (2003) states that religion is not necessarily needed for spirituality but conversely spirituality is needed for religion. From this perspective, the existence of spirituality on individual is definitely important than that of religion. Spiritual values and spiritual practices in workplace and in leadership can therefore be inclusive or exclusive of any religious theory and practice.

The interactive effects have shown us that the spiritual values that the leaders profess must truly in line with the real actions — called spiritual practices. Spiritual practices strengthen the relation of spiritual values and leadership effectiveness. The positive-interactive effects mean that the effect of spiritual values to leadership effectiveness will debilitate when leaders do not practice the values. Conversely, leaders will be much more effective when they keep spiritual values as well as spiritual practices.

After analyzing the interaction among these three variables, as we expect, we find in the test that spiritual practices moderate the relation of spiritual values and leadership effectiveness. The small percentage $4 \%$ in the test looks to be complicated to interpret. Hypothesis $1 \& 2$, 
which are really supported by the test, seem to change unpredictably in the moderating test. This result of the test emphasized that both spiritual values and spiritual practices should be demonstrated in the workplace.

Freeman (2011) views spiritual practices as a moderating variable between leader's servant leadership behavior and leadership effectiveness. In this study, spiritual practices clearly moderate the spiritual values and leadership effectiveness. This finding is a new point of view of spiritual leadership. From the result, we can postulate that leaders who have spiritual values, but do not practice the values that they have, will be less effective than the leaders who have spiritual values and practicing their values. Reave (2005) in her meta-analysis firmly proves that spiritual values and spiritual practices affect the leadership effectiveness. But she does not really reveal those relations whether they have positive-or-negative-interactive effects or positive-or-negative-mediating effects. This research will add more findings regarding spiritual leadership theory. Hypothesis 3, which predicts that spiritual values and spiritual practices have interactive effects on leadership effectiveness such that leaders who implement spiritual values and spiritual practices will perform the greatest success, is also supported.

Proselytizing or persuading individuals is not the main essence of spirituality in the workplace. In the context of effective leadership, we perceive that spirituality expresses itself not so much in words or preaching, but in the embodiment of spiritual values such as working as calling, integrity, honesty, Humility, and in the demonstration of spiritual behavior such as expressing respect for others' values, fair treatment, caring and concern, listening, appreciating others, and reflective practices (Reave, 2005).

Lerner (2000) states that people require a balance between outer work and inner work so that people will benefit themselves as well as others' selves. A lot of grassroots leaders endorse the importance of spirituality in their efforts and struggles. For example, Arabia before Islam was without social amenity or historical depth, and the Arabs lived in moral bankruptcy and spiritual servitude. The prophet Muhammad spreads Islam by demonstrating the value of spirituality - in the Arabic terms: Siddig, Amanah, Tablig, Fathonah — to his followers (Razwy, 2014). Gandhi efforts India to declare the independence in a spiritual tenet of non-violence (ahimsa) (Dorn, 2001). Martin Luther King, Jr. leads to fight against the violence by the spirit of agape (Yasuno, 2008).

\section{Conclusion}

In this study, we seek to examine empirically those spiritual values and spiritual practices have interactive effects on leadership effectiveness. In this research, spiritual values and spiritual practices are articulated to be more in demonstrating attitude and behavior. Spiritual value dimensions are working as calling, integrity, honesty, Humility; spiritual practices are expressing respect for others' values, caring and concern, listening, appreciating others, and reflective practices while leadership effectiveness is measured by the followers' feedback (perception, motivation, satisfaction, retention, ethic, and organization citizenship behavior)

The significantly positive relationship among spiritual values, spiritual practices, 
and leadership effectiveness shows that spiritual values and spiritual practices positively affect leadership effectiveness. This study also emphasizes that spiritual values and spiritual practices have the interactive effects on leadership effectiveness such that leaders who implement spiritual values and spiritual practices will perform great success. As the spiritual practices moderates the effect of spiritual values to leadership effectiveness, the effectiveness increases as leaders and followers or employees truly have spiritual values as well as spiritual practices. Therefore, organizations or companies need to keep and even upgrade the people's spiritual values and spiritual practices in their environment to maintain effectiveness and gain success.

The study has several limitations that deserve notice. The small number of samples is one of some obstacles that the author faced. In addition, the use of respondents in a single organization made this research rigid to be generalized outside the environment of the population. Future research should collect more data from varying organizations to make this research able to be generalized. We measured the variables based on the internal-capital values of leaders and followers themselves. This circumstance generates a question whether the leaders and followers filled the questionnaire in good mood and in stable emotion. Longitudinal analyses might be better for future research with deeper method such as, lab experiment with control variable. Finally, the new model of this relation should be examined to know whether there is mediating or other variables concerning spirituality and leadership.

\section{References}

Alleyne, P., Cadogan-McClean, C., \& Harper, A. (2013). Examining Personal Values and Ethical Behaviour Perceptions Between Accounting and Non-Accounting Students in the Caribbean. The Accounting Educators' Journal. Vol. 23: 47-70.

Ashforth, B., \& Pratt, M. (2014). Institutionalized Spirituality: An Oxymoron? In Giacalone, R.A., \& Jurkiewicz, C.L. (Eds). Handbook of Workplace Spirituality and Organizational Performance. London: Taylor \& Francis.

Baron, R. M., \& Kenny, D. A. (1986). The Moderator-Mediator Variable Distinction in Social Psychological Research: Conceptual, Strategic, and Statistical Considerations. Journal of Personality and Social Psychology. Vol. 51(6): 1173-1182.

Barret, R. (2014). Culture and consciousness: Measuring spirituality in the workplace by mapping values. In Giacalone, R.A., \& Jurkiewicz, C.L. (Eds). Handbook of Workplace Spirituality and Organizational Performance. London: Taylor \& Francis.

Beheshtifar, M., \& Zare, E. (2013). Effect of Spirituality in Workplace on Job Performance. Interdisciplinary Journal of Contemporary Research in Business. Vol. 5(2): 248-256.

Bodling, A., Heneghan, M., Walsh, J., Yoon, D., \& Johnstone, B. (2013). The Brief Multidimensional Measure of Religiousness/Spirituality with an Irish sample: a Factor Analysis. International Journal of Therapy and Rehabilitation. Vol. 20 (2): 201-210. DOI: https://doi.org/10.12968/ijtr.2013.20.2.72 
Bolman, L. G., \& Deal, T. E. (2011). Leading with Soul: An Uncommon Journey of Spirit (3 ${ }^{\text {rd }}$ Ed). San Francisco, CA: Jossey-Bass.

Cavanagh, G.F. (1999). Spirituality for Managers: Context and Critique. Journal of Organizational Change Management. Vol. 12(3): 186-199. DOI: https://doi. org/10.1108/09534819910273793

Denison, D. R., Hooijberg, R., \& Quinn, R. E. (1995). Paradox and performance: Toward a theory of behavioral complexity in managerial leadership. Organization Science, 6(5), $524-540$.

Dik, B. J., Eldridge, B. M., Steger, M. F., \& Duffy, R. D. (2012). Development and Validation of the Calling and Vocation Questionnaire (CVQ) and Brief Calling Scale (BCS). Journal of Career Assessment. Vol. 20(3): 242-263. DOI: https://doi. org/10.1177/1069072711434410

Dorn, A. W. (2001). Lotus on The Lake: How Eastern Spirituality Contributes to The Vision of World Peace. Journal of Oriental Studies. Vol. 11: 156-166.

Dyson, J., Cobb, M., \& Forman, D. (1997). The Meaning of Spirituality: A Literature Review. Journal of Advanced Nursing. Vol. 26(6): 1183-1188.

Ehigie, B.O., \& Akpan, R.C. (2004). Roles of Perceived Leadership Styles and Rewards in The Practice of Total Quality Management. Leadership and Organization Development Journal. Vol. 25(1): 24-40. DOI: https://doi.org/10.1108/01437730410 512750.

Francis, R. E. (2013). Development of a Personality-Based Measure of Integrity. Saint Mary's University, Canada. Retrieved from http://www.worldcat.org/title/development-of-apersonality-based-measure-of-integrity/oclc/851631159

Freeman, G. T. (2011). Spirituality and Servant Leadership: A Conceptual Model and Research Proposal. Emerging Leadership Journeys. Vol. 4(1): 120-140.

Fry, L. W. (2003). Toward a Theory of Spiritual Leadership. The Leadership Quarterly. Vol. 14(6): 693-727. DOI: https://doi.org/10.1016/j.leaqua.2003.09.001

Gupta, A., McDaniel, J. C., \& Kanthi Herath, S. (2005). Quality Management in Service Firms: Sustaining Structures of Total Quality Service. Managing Service Quality: An International Journal. Vol. 15(4): 389-402.

Hair, J., Anderson, R., Black, B., \& Babin, B. (2016). Multivariate Data Analysis. New Jersey: Pearson Education.

Hardt, J., Schultz, S., Xander, C., Becker, G., \& Dragan, M. (2012). The Spirituality Questionnaire: Core Dimensions of Spirituality. Psychology. Vol. 3(1): 116-122. DOI: https://doi.org/10.4236/psych.2012.31017

Harrison, J. (1993). Spirituality and Nursing Practice. Journal of Clinical Nursing. Vol. 2(4): $211-217$.

Javanmard, H. (2012). The Impact of Spirituality on Work Performance. Indian Journal of Science and Technology. Vol. 5(1): 1961-1966. DOI: https://doi.org/10.17485/ ijst/2012/v5i1/30966 
Josephson, M. S. (2002). Making Ethical Decisions (2002 edition). Marina del Rey, CA: Josephson Institute of Ethics.

Lee, K., Ashton, M. C., Morrison, D. L., Cordery, J., \& Dunlop, P. D. (2008). Predicting Integrity with The HEXACO Personality Model: Use of Self- and Observer Reports. Journal of Occupational and Organizational Psychology. Vol. 81(1): 147-167. DOI: https://doi.org/10.1348/096317907X195175

Marques, J., Dhiman, S., \& King, R. (2005). Spirituality in The Workplace: Developing an Integral Model and a Comprehensive Definition. Journal of American Academy of Business. Vol. 7(1): 81-91.

Maxwell, T. P. (2003). Integral Spirituality, Deep Science, and Ecological Awareness. Zygon ${ }^{\bullet}$ Vol. 38(2): 257-276.

Melchar, D. E., \& Bosco, S. M. (2010). Achieving High Organization Performance Through Servant Leadership. The Journal of Business Inquiry. Vol. 9(1): 74-88.

Mitroff, I. I., \& Denton, E. (1999). A Study of Spirituality in the Workplace. MIT Sloan Management Review. Retrieved from https://sloanreview.mit.edu/article/a-study-ofspirituality-in-the-workplace/

Moxley, R. S. (1999). Leadership and Spirit ( $1^{\text {st }}$ ed). San Francisco: Jossey-Bass.

Nadesan, M. H. (1999). The Discourses of Corporate Spiritualism and Evangelical Capitalism. Management Communication Quarterly. Vol. 13(1): 3-42.

Nasr, S. H. (1968). The Encounter of Man and Nature: The Spiritual Crisis of Modern Man. Michigan: George Allen \& Unwin Limited.

Neal, J. A., \& Bennett, J. (2000). Examining Multi-Level or Holistic Spiritual Phenomena in the Work Place. Management, Spirituality, and Religion Newsletter, Academy of Management, 1-2.

O'connell, K. A., \& Skevington, S. M. (2005). The Relevance of Spirituality, Religion and Personal Beliefs to Health-Related Quality of Life: Themes from Focus Groups in Britain. British Journal of Health Psychology. Vol. 10(3): 379-398.

Rafferty, A. E., \& Griffin, M. A. (2004). Dimensions of Transformational Leadership: Conceptual and Empirical Extensions. The Leadership Quarterly. Vol. 15(3): 329-354. DOI: https://doi.org/10.1016/j.leaqua.2004.02.009

Razwy, S. A. A. (2014). A Restatement of the History of Islam and Muslims. North Carolina: Lulu Press, Inc.

Reave, L. (2005). Spiritual Values and Practices Related to Leadership Effectiveness. The Leadership Quarterly. Vol. 16(5): 655-687. DOI: https://doi.org/10.1016/j.leaqua. 2005.07.003

Ting, S.-C. (2013). Service Fairness Scale: Development, Validation, and Structure. International Journal of Marketing Studies. Vol. 5(6): 25-36. DOI: https://doi.org/10. 5539/ijms.v5n6p25

Wagner-Marsh, F., \& Conley, J. (1999). The Fourth Wave: The Spiritually-Based firm. Journal 
of Organizational Change Management. Vol. 12(4): 292-302. DOI: https://doi.org/10. 1108/09534819910282135

Yasuno, M. (2008). The Role of Spirituality in Leadership for Social Change. Spirituality in Higher Education Newsletter. Vol. 4(3): 1-4.

Zinnbauer, B. J., Pargament, K. I., Cole, B., Rye, M. S., Butter, E. M., Belavich, T. G., \& Kadar, J. L. (1997). Religion and Spirituality: Unfuzzying the Fuzzy. Journal for the Scientific Study of Religion. Vol. 36(4): 549-554. DOI: https://doi.org/10.2307/ 1387689

Zohar, D. (2012). Spiritual Intelligence: The Ultimate Intelligence. London: Bloomsbury Publishing. 